16. SITE 226

The Shipboard Scientific Party ${ }^{1}$

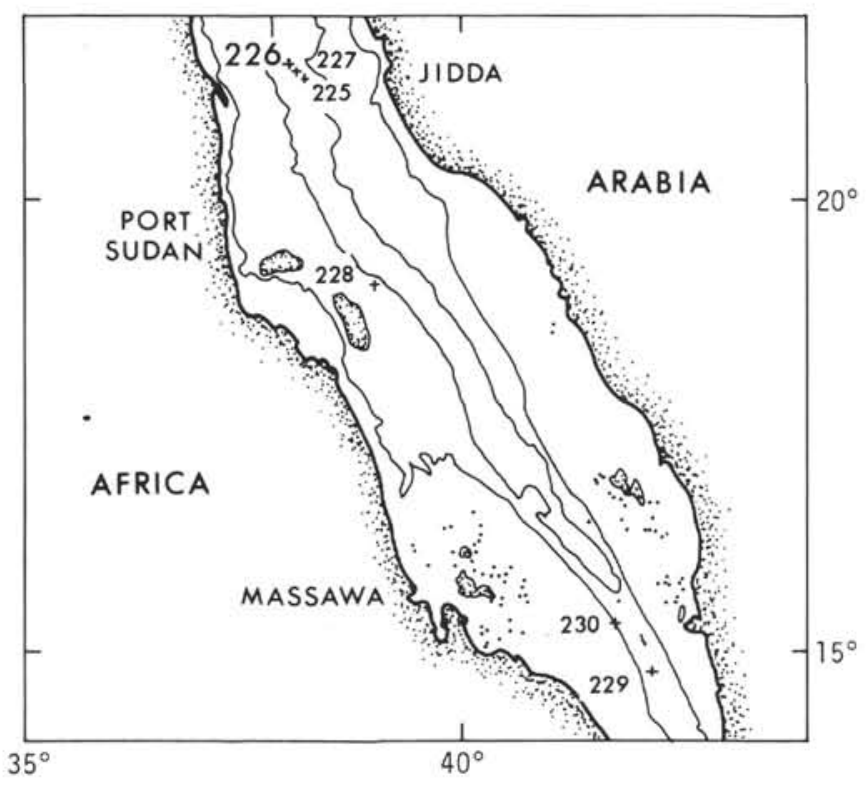

Figure 1. Bathymetric chart showing the position of Site 226 and other Leg 23 sites in the Red Sea. Contours at 500 and 1000 fathoms, from Laughton (1970).

\section{SITE DATA}

Dates: 024517 Apr-1000 18 Apr 72

Time: 31 hours

Position (Figure 1): $21^{\circ} 21.51^{\prime} \mathrm{N}, 38^{\circ} 09.93^{\prime} \mathrm{E}$

Holes Drilled: 6 attempted

Water Depth by Echo-Sounder: 2169 corr. meters, not corrected for the sound velocity of the brines,

Total Penetration: 14 meters

Age of Oldest Sediment: Late Pleistocene

Basement: Probably not reached, prevented by basalt

\section{ABSTRACT}

Site 226 was drilled in the central part of the axial trough in an area with bottom water of very high temperature and salinity (about $60^{\circ} \mathrm{C}$ and $260^{\circ} \%$, respectively). The drilling was done in an area commonly known as the hot brine area, and more particularly, in the Atlantis II Deep. This was a high risk hole in that it was not clear if enough sediment was present to satisfactorily bury the drill string, and indeed, drilling attempts at three different offset positions failed to penetrate a shallow basalt. Only a total of 14 meters was penetrated before part of the bottom hole assembly was lost.

The two cores we obtained contained sediments similar to those previously obtained from the area-a Late Quaternary mixed montmorillonite, anhydrite, and goethitehematite facies in the upper 5 meters with fresh basalt fragments in the lower 9 meters. The basalts, which show no indications of chemical reaction with the hot brines, are similar to previously described oceanic ridge basalts.

Geochemically, the sediments recovered at Site 226 are similar to those previously collected except for the lower quantities of manganese and higher amounts of barium and lead.

\section{BACKGROUND AND OBJECTIVES}

Site 226 was drilled in the axial trough of the Red Sea (Figure 1) in an area having bottom water with anomalously high water temperatures and salinities (the so-called hot brine area).

The first indication of anomalous temperatures and salinities in the central portion of the Red Sea near $21^{\circ} \mathrm{N}$ was noted, by chance, on the Swedish vessel Albatross in 1948. The Swedish scientists thought their values of bottom temperature and salinity of about $24.5^{\circ} \mathrm{C}$ and $45 \%$, respectively, were due to faulty equipment (normal bottom conditions are about $20-22^{\circ} \mathrm{C}$ and $40^{\circ} \%$ ). However, the typically curious British marine scientists thought that these values could indeed be real and later severar voyages of R.R.S. Discovery, of Britain, and R.V.Atlantis, of Woods Hole, corroborated these slightly anomalous values. It was not until 1964 that Swallow and Crease (1965) found, in what is now called the Discovery Deep, a brine with a temperature of $44^{\circ} \mathrm{C}$ and a salinity of $256^{\circ} \%{ }^{2}$ In 1965 Miller and others found, in what is called the Atlantis II Deep, bottom waters of $56^{\circ} \mathrm{C}$ and similar salinities (Miller et al., 1966). A third deep, the Chain Deep, was found in 1966 (Ross and Hunt, 1967). In 1966, a detailed study of the brine area was made from the Woods Hole vessel, Chain. Among the highlights of that expedition (Degens and Ross, 1969) was finding that sediments underlying the brine were enriched in heavy metals (copper, zinc, lead, silver, and gold). Much of the data indicate that the brines originate from discharge into the Atlantis II Deep with subsequent overflows into the Chain and Discovery deeps.

A more recent Woods Hole expedition to the area in 1971 has found that the waters of the Atlantis II Deep have

\footnotetext{
${ }^{1}$ Robert B. Whitmarsh, National Institute of Oceanography, Wormley, Godalming, Surrey, United Kingdom; David A. Ross, Woods Hole Oceanographic Institution, Woods Hole, Massachusetts; Syed Ali, State University of New York, Stony Brook, New York; Joseph E. Boudreaux, Texaco, Inc., New Orleans, Louisiana; Robert Coleman, U. S. Geological Survey, Menlo Park, California; Robert L. Fleisher, University of Southern California, Los Angeles, California; Ronald W. Girdler, The University, Newcastle-upon-Tyne, United Kingdom; Frank T. Manheim, U. S. Geological Survey, Woods Hole, Massachusetts; Albert Matter, Geologisches Institut, Universität, Bern, Switzerland; Catherine Nigrini, Lexington, Massachusetts; Peter Stoffers, Laboratorium für Sedimentforschung, Universität Heidelberg, Heidelberg, Germany; Peter R.Supko, Scripps Institution of Oceanography, La Jolla, California
} 
heated up (Brewer et al., 1971; Ross, 1971); bottom water temperatures were then $59.2^{\circ} \mathrm{C}$. This increase is equivalent to an input of about $700 \mathrm{gal} / \mathrm{sec}$ of brine having a temperature of $104^{\circ} \mathrm{C}$. The increase in temperature clearly indicates the present activity of the area. Another finding was that of former brine deeps covered by younger sediments.

The similarity of the heavy metal deposits with some ancient ore formations indicates that conditions in the Red Sea may be a counterpart of those that formed the ancient deposits. That the brine deposits occur in a zone of sea-floor spreading suggests a mechanism that may be common to other present and ancient rift zones.

Site 226 is in the southwestern part of the Atlantis II Deep. Previous seismic reflection work (Ross et al., 1969) indicated that this was the area of maximum sediment thickness. Sediment thicknesses are difficult to estimate from seismic profiles because of the steep relief and side reflections.

The objectives of drilling at this site were:

1) What is the extent, nature, and origin of the heavy metal-rich deposits?

2) Do older and metal-rich sediments exist below the underlying basalt?

3) How have the brines affected (or been affected by) the basement rocks?

4) To obtain geological and geophysical data from a spreading center.

The JOIDES Advisory Panel on Pollution Prevention and Safety suggested continuous coring and monitoring of downhole temperature for all Red Sea sites.

\section{OPERATIONS}

Site 226 was approached from the east after departing from Site 225 (Figure 2). A course was set to the southwest corner of Atlantis II Deep, and seismic profiling was carried out at 8 knots. When the mid-water reflection from the top of the brine had been identified, speed was reduced to 5 knots. The profile across the deep seemed to indicate a layered sequence which was interpreted to be sediment. A $13.5 \mathrm{kHz}$ beacon was dropped at 5 knots, and the ship returned to the beacon when all the gear had been brought aboard.

Drilling at Site 226 was very difficult. Prior to drilling, a temperature probe was lowered to obtain a temperature profile in the hot brines. Drilling started with 2208 meters of pipe out, and up to $10,000 \mathrm{lb}$ weight on the bit was necessary to penetrate the upper 5 meters. A hard layer was encountered at about 2.5 meters, and basalt fragments were obtained in the punch core catcher. The hole was lost while attempting to cut Core 2 and a new one had to be cut. This time penetration was to 14 meters, with again as much as $10,000 \mathrm{lb}$ weight needed on the bit. Several hard, probably basaltic, layers were encountered. The pipe was withdrawn from the hole during core removal, and the hole was again lost.

\footnotetext{
${ }^{2}$ Not salinity in the true oceanographic sense of the word since the ratios of many of the major and minor elements in the brine are different from those in normal seawater.
}

A new hole was started for Core 3, and again a hard layer was encountered at about $2-3$ meters. Bit weight was kept at $10,000 \mathrm{lb}$ or less. However, the lower portion of the drilling assembly was broken off at a depth of 2211 meters while working into the hole. The lower two bumper subs, four drill collars, and a core barrel and bit were lost. The remaining drill string was brought back aboard and we set off for Hole 226A, which was 300 feet west-northwest of Hole 226. A hard bottom was again encountered and we were unable to core it. This hole was abandoned and a new hole (Hole 226B) was attempted 500 feet south and 400 feet east of the beacon. Again, a hard bottom was encountered at 2203 meters, and we were unable to core it. A third offset (Hole 226C), 600 feet east and 100 feet south of the beacon, again hit a hard bottom at 2205 meters and we were unable to core. It was decided at this time to pull the drill string and proceed to Site 227.

Glomar Challenger left Site 226 at 1000 hours on 18 Apr 72. The gear was streamed while the ship headed west. Before returning to Site 227, a short survey of Valdivia Deep, newly discovered by the Preussag team onboard Valdivia, was made which indicated that insufficient sediments, if any, were present for drilling to be contemplated at that place.

On the ship's return to Atlantis II Deep, we passed over the Site 226 sea-bed beacon to obtain a continuous profile across the site.

\section{LITHOLOGY}

Because of coring difficulties (hard bottom), only two cores were recovered at Site 226. These cores were intensely disturbed. They probably penetrated the different brine facies described by Bischoff (1969), but these could not be differentiated. Basalt fragments were obtained only a few meters below the sediment surface.

The stratigraphic section, 14 meters in thickness, is made up of two different units as shown in Table 1.

\section{Unit I}

Dark reddish montmorillonite mixed with goethitehematite and anhydrite is the main mineral facies in the badly distorted cores. Section 3 of Core 1 is less disturbed and consists of dusty red anhydrite-bearing hematite. Several 1 to 5 -cm-thick white anhydrite layers were found in this unit. The beds are composed of very pure wellcrystallized anhydrite.

According to Bischoff (1969), the Red Sea geothermal deposits can be divided into seven distinct facies. Although the cores were badly disturbed, the mineralogy and the chemical data of the mixed core sediments indicate that the cores penetrated at least the montmorillonite, goethitehematite, and anhydrite facies. X-ray shore-lab studies reveal the abundant occurrence of sphalerite in one sample. This indicates that the sulfide facies may also be mixed in the disturbed core sections.

\section{Unit II}

The rift zone basalts are present only a few meters below the sea bed in the hot brine area. Fragmental samples of basalt and basaltic glass were present in all the core barrels. The maximum size does not exceed $4 \mathrm{~cm}$, and it was not 


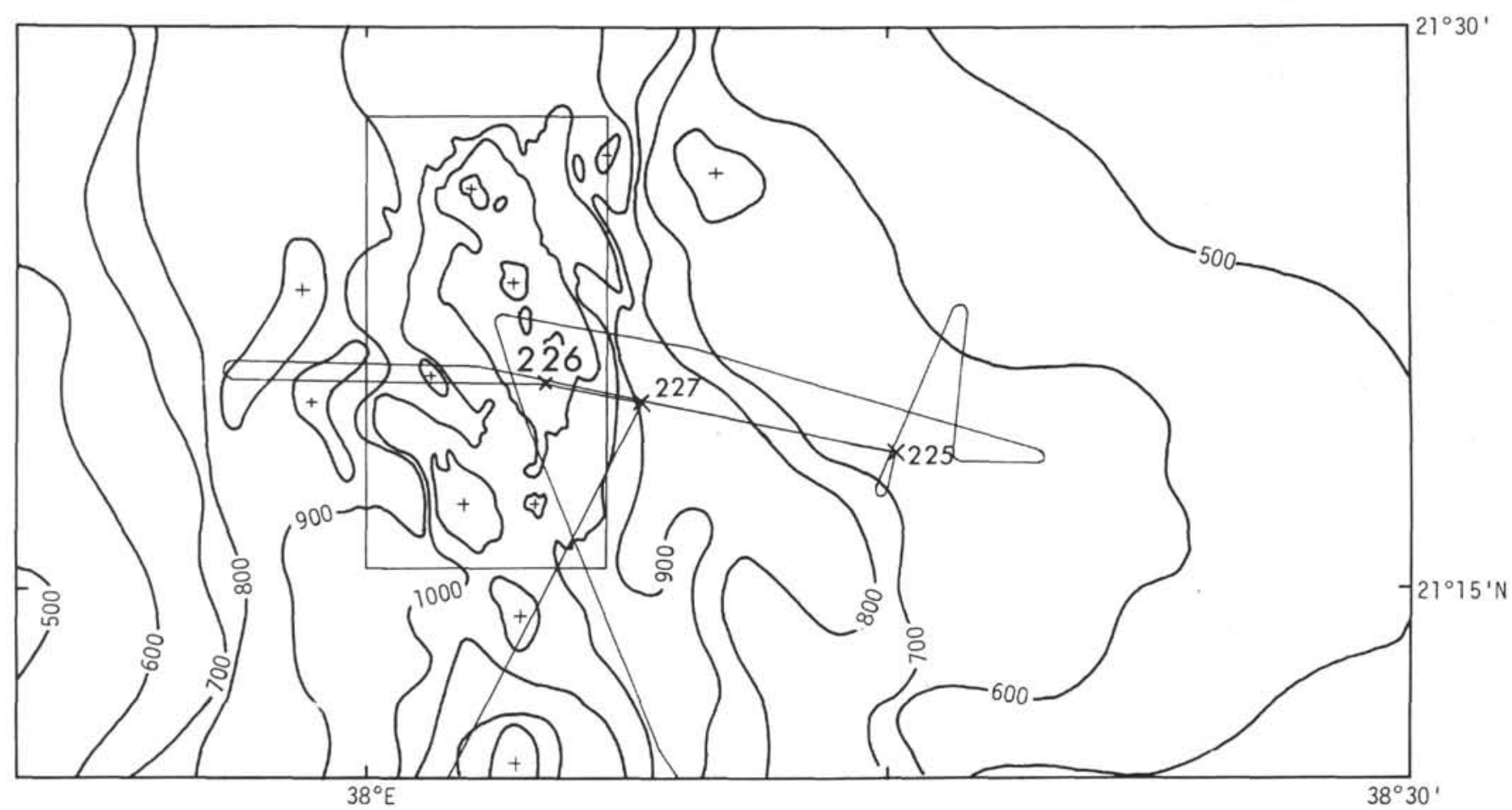

Figure 2. Bathymetric chart of the area around Sites 225, 226, and 227 with the tracks of Glomar Challenger. Contour interval 100 fathoms, depths in corrected fathoms. Contours within box from Amann (1972), other contours based on collected soundings too numerous to show clearly (after Laughton, unpublished).

possible to determine if the fragments represent more than one flow. Although these fragments were broken during drilling, some show chilled glassy margins up to $3 \mathrm{~cm}$ thick. These chilled margins represent the outer surface of pillows or the top parts of extruded lava. Vesiculation is less than 1 percent by volume of the rock with the vesicles ranging in size from 0.2 to $0.3 \mathrm{~mm}$. Plotting the vesicle size on Moore's (1970) curve of vesicle size against ocean depth for pillow lavas shows close agreement between predicted depth and the actual depth of about 2200 meters.

The glassy margins (refractive index 1.60) grade into variolitic basalt containing plagioclase microlites $(A n \sim 48)$ and feathery crystallites of clinopyroxene. Phenocrysts (up to $1.5 \mathrm{~mm})$ of corroded plagioclase $\left(\mathrm{An}_{55}\right)$ exhibiting oscillatory zoning make up less than $1 \%$ of the basalt. Euhedral to subhedral olivine (Fo85) phenocrysts form clots or groupings with the plagioclase phenocrysts. Where cooling was slower than the chilled margins, the basalt textures are intersertal to intergranular with pale brown clinopyroxene (refractive index $=1.69$ and optical axial angle moderate) developing from the glass in areas between the feldspar laths.

The presence of corroded calcic plagioclase and forsteritic olivine as large phenocrysts indicates an earlier deeper level and higher temperature partial crystallization of the basalt melt prior to its extrusion in the brine area. Cumulates of the early crystallized olivine and plagioclase on the floors of intermediate depth ( 2 to $5 \mathrm{~km}$ ) magma chambers could give rise to layered gabbros and perhaps explain the high compressional wave velocities $(7 \mathrm{~km} / \mathrm{sec}$ ) observed under the central rift zone of the Red Sea. The
TABLE 1

Lithologic Summary, Site 226

\begin{tabular}{|c|c|c|c|c|c|}
\hline \multicolumn{3}{|c|}{ Lithologic Units } & $\begin{array}{c}\text { Thickness } \\
\text { (m) }\end{array}$ & $\begin{array}{c}\text { Depth } \\
\text { (m) }\end{array}$ & Core \\
\hline I & $\begin{array}{l}\text { MONTMORILLONITE } \\
\text { ANHYDRITE } \\
\text { GOETHITE-HEMATITE }\end{array}$ & \} mixed & 5 & $0-5$ & 1 \\
\hline II & BASALT & & 9 & $5-14$ & 1,2 \\
\hline
\end{tabular}

mineralogic nature of these basalts is similar to deep ocean tholeiitic basalts and the analyses (Tables 2, 3, and 4) further confirm this similarity.

The basalts are typical of previously described ocean ridge basalts which characteristically have low alkalis and unfractionated rare earths. The remarkably unaltered nature of these rocks is confirmed by the analyses (Tables 2,3 , and 4 ), and this leads to the observation that chemical coherence between the basalt and its quenched glass indicates that there was no chemical reaction of the basalt and the hot brine solutions during its cooling.

\section{BIOSTRATIGRAPHY}

\section{Foraminifera}

Three samples, taken from within the sediment sequence recovered from Site 226, contain a small but fairly well preserved Late Quaternary fauna, consisting of the four or five species commonly reported from Red Sea samples of this age. No benthonic foraminifera were found. 


\section{Nannofossils}

At Site 226 nannofossils are rare and some species are pooly preserved.

The core catcher of Core 1 contains Late PleistoceneRecent nannofossils belonging to the Gephyrocapsa oceanica Zone with rare specimens of poorly preserved Gephyrocapsa oceanica and few specimens of Ellipsodiscoaster lidzi and Syracosphaera histrica.

\section{Radiolaria} site.

No radiolarians were found in material recovered at this

\section{Biostratigraphic Summary}

Radiolarians were absent in the sediments recovered at this site, and nannofossils were present only in Sample 1, CC. Planktonic foraminifera were found in three samples from within Core 1. All observed faunas indicate a Late Quaternary age for these sediments.

TABLE 2

Chemical Analyses of Basalt and Basaltic Glass from Core 226-2-1a

\begin{tabular}{|c|c|c|c|c|}
\hline & $\begin{array}{c}\text { Basalt } \\
\mathrm{A}\end{array}$ & $\begin{array}{c}\text { Basalt } \\
\text { B }\end{array}$ & $\begin{array}{c}\text { Basalt } \\
\text { C }\end{array}$ & $\begin{array}{c}\text { Glass } \\
\text { D }\end{array}$ \\
\hline $\mathrm{SiO}_{2}$ & 50.2 & 49.8 & 50.0 & 50.0 \\
\hline $\mathrm{Al}_{2} \mathrm{O}_{3}$ & 15.0 & 15.6 & 15.3 & 15.4 \\
\hline $\mathrm{Fe}_{2} \mathrm{O}_{3}$ & 1.5 & 1.5 & 1.5 & 1.0 \\
\hline $\mathrm{FeO}$ & 9.2 & 9.1 & 9.2 & 9.7 \\
\hline $\mathrm{MgO}$ & 7.9 & 7.8 & 7.9 & 8.2 \\
\hline $\mathrm{CaO}$ & 11.6 & 11.5 & 11.5 & 12.0 \\
\hline $\mathrm{Na}_{2} \mathrm{O}$ & 2.6 & 2.5 & 2.5 & 2.5 \\
\hline $\mathrm{K}_{2} \mathrm{O}$ & 0.06 & 0.03 & 0.03 & 0.03 \\
\hline $\mathrm{H}_{2} \mathrm{O}^{+}$ & 0.47 & 0.40 & 0.90 & 0.57 \\
\hline $\mathrm{H}_{2} \mathrm{O}^{-}$ & 0.26 & 0.60 & 0.25 & 0.04 \\
\hline $\mathrm{TiO}_{2}$ & 1.3 & 1.3 & 1.3 & 1.3 \\
\hline $\mathrm{P}_{2} \mathrm{O}_{5}$ & 0.15 & 0.14 & 0.12 & 0.12 \\
\hline $\mathrm{MnO}$ & 0.15 & 0.14 & 0.12 & 0.12 \\
\hline $\mathrm{CO}_{2}$ & 0.04 & 0.06 & 0.06 & 0.01 \\
\hline Total & 100.4 & 100.5 & 100.7 & 101 \\
\hline $\begin{array}{l}\text { Powder } \\
\text { density }\end{array}$ & 3.04 & 3.00 & 3.00 & 2.88 \\
\hline
\end{tabular}

\begin{abstract}
${ }^{\mathrm{a}}$ Analysis performed in the Rapid Rock Analysis Laboratory by Sam Botts, U. S. Geological Survey, Washington, D. C. Samples A, B, C represent broken fragments from the same core barrel. A consists of fragments about $6 \mathrm{~mm}$; B consists of fragments between 1.2 and $1.5 \mathrm{~cm} ; \mathrm{C}$ consists of fragments about $1.2 \mathrm{~mm}$; and D consists of fragments of glass separated from the basalt. All samples were ground in ceramic vessels and splits made for the various types of analyses.
\end{abstract}

\section{GEOCHEMISTRY}

\section{Solids}

The initial punch core into the Atlantis II Deep sediments brought up a badly mixed and distorted sediment, consisting of black, sulfide and heavy-metal-rich mud, anhydrite, and basalt fragments. The blackness, the character of the sediments, and the spectrographic analyses
TABLE 3

Analyses of Minor Elements (ppm) by Emission Spectrography of Basalt and Basaltic Glass from Core $226-2-1^{\text {a }}$

\begin{tabular}{lrrrr}
\hline & Basalt & Basalt & Basalt & \multicolumn{1}{c}{ Glass } \\
& $\mathrm{A}$ & $\mathrm{B}$ & $\mathrm{C}$ & \multicolumn{1}{c}{$\mathrm{D}$} \\
\hline $\mathrm{Mn}$ & 1300 & 1300 & 1400 & 1200 \\
$\mathrm{Ba}$ & 20 & 16 & 16 & 50 \\
$\mathrm{Co}$ & 48 & 48 & 48 & 44 \\
$\mathrm{Cr}$ & 300 & 400 & 400 & 400 \\
$\mathrm{Cu}$ & 110 & 110 & 110 & 110 \\
$\mathrm{Ni}$ & 100 & 110 & 95 & 95 \\
$\mathrm{Sc}$ & 70 & 95 & 70 & 60 \\
$\mathrm{Sr}$ & 80 & 120 & 100 & 120 \\
$\mathrm{~V}$ & 310 & 300 & 300 & 310 \\
$\mathrm{Y}$ & 60 & 60 & 60 & 50 \\
$\mathrm{Zr}$ & 60 & 70 & 70 & 60 \\
$\mathrm{Yb}$ & 5 & 6 & 6 & 5 \\
\hline
\end{tabular}

aR. E. Mays, analyst, U.S. Geological Survey, Menlo Park.

TABLE 4

Analysis of Minor Elements (ppm) by Neutron Activation of Basalt from Core 226-2-1a

\begin{tabular}{lccl}
\hline & $\begin{array}{c}\text { Basalt } \\
\text { A }\end{array}$ & $\begin{array}{c}\text { Basalt } \\
\text { B }\end{array}$ & $\begin{array}{c}\text { Basalt } \\
\text { C }\end{array}$ \\
\hline $\mathrm{La}$ & 2.4 & 2.1 & 3.0 \\
$\mathrm{Ce}$ & 15.0 & 10.0 & 7.0 \\
$\mathrm{Sm}$ & 2.7 & 3.0 & 3.0 \\
$\mathrm{Eu}$ & 1.2 & 1.3 & 1.3 \\
$\mathrm{~Tb}$ & 0.9 & 0.8 & 0.9 \\
$\mathrm{Yb}$ & 2.8 & 3.2 & 3.0 \\
$\mathrm{Lu}$ & 0.60 & 0.62 & 0.56 \\
$\mathrm{Hf}$ & 2.9 & 2.2 & 2.0 \\
$\mathrm{Th}$ & 0.3 & 0.1 & 0.3 \\
$\mathrm{Ta}$ & 0.2 & 0.2 & 0.3 \\
\hline a David Cole, analyst, Oregon State University.
\end{tabular}

(Manheim and Siems, Chapter 29) suggest that the sediments are mainly from the black "iron montmorillonite" facies of Bischoff (1969), together with some goethite-hematite facies. However, there are some chemical differences. Unlike the previously described metalliferous sediments from the hot brine deeps, these had much less manganese (less than $0.1 \% \mathrm{Mn}$ ), but considerably more barium (more than 0.5\%) and lead (up to $0.5 \%$ ), even without correcting for the considerable brine salt in the dried residues. The lead concentrations are among the highest hitherto described from this area. What makes this puzzling is that the samples from Site 225, as well as 227, showed very meager lead concentrations, so little in fact that we were hard pressed to find any lead-rich phases even in pyrite or segregations for lead isotope analysis. On the other hand, $0.7 \% \mathrm{Cu}$, possibly several percent zinc, and 50 to $100 \mathrm{ppm}$ silver, which were found, may be considered normal for the upper part of the brine sediment sequence (Bischoff, 1969).

Examination of two pieces of basalt, a chilled glassy margin, and a more porphyritic inner portion found normal 
amounts of iron, magnesium, titanium (about $0.7 \% \mathrm{Ti}$ ), chromium, and other constituents, but no unusual amounts of heavy metals such as copper, zinc, lead, molybdenum, etc. There is no evidence from this site that the basalts are either a source of metals or have been impregnated by metals of sedimentary origin.

\section{Fluids}

Although the sediments were visibly disturbed, and in part were little more than a black porridge soup, samples were taken for interstitial water analyses. Refractometry on extracted waters from Sections 1 and 2 of Core 1 yielded salinities (after weight dilution to bring the brines within the range of our Goldberg refractometers) of 256 and 255 $\%$ (Table 5). These values are very close to previous values of 256 and 257 obtained for waters of the Atlantis II brine deep. Two samples from Sections 3 and 4 of Core 1 yielded, surprisingly, higher values of $264 \%$. One must note that the refractometer has not been calibrated to give precise total salt content for the ionic mix characteristic for the hot brine deeps, although refractive index is much less sensitive to ionic variability in brines than is electrical conductivity. For the latter samples, one cannot exclude some evaporation in the course of handling and manipulating the cores. The sediments were still warm and evaporated readily in the core laboratory; the mushy material might also pick up salt crystals from a dried surface. This point needs investigation, for previous experiments have shown that saturation of these brines with excess sodium chloride occurs at a salt content of about $260 \%$ o.

All waters were glass clear when squeezed, but became cloudy reddish-yellow after several hours, suggesting iron precipitation. Examination of the dried salt by the spectrograph (Manheim et al., Chapter 35) shows the equivalent in fresh brine of $25 \mathrm{ppm} \mathrm{Mn}$ and $40 \mathrm{ppm} \mathrm{Sr}$, in addition to the major constituents. A curious observation was that some of the black material actually tloated up in the brine, as though it were lighter than the brine at Sp. G. of about 1.20. This has not yet been explained. The details of brine chemistry is discussed further in the Geochemistry section.

No water content measurements were made in view of the disturbed nature of the sediments.

\section{Isotope Studies}

Delevaux and Doe (this volume) have measured uranium, thorium, and lead contents and the lead isotopic composition of a single sediment sample from this site.

\section{CORRELATION OF REFLECTION PROFILES AND LITHOLOGIES}

No clear subbottom reflectors have been identified on seismic profiles obtained by sparkers or airguns across the Atlantis II Deep. In part, this can be attributed to the interference of side reflections from the slopes bounding the deep, but it undoubtedly also indicates that only a minimal amount of sediment overlies volcanic basement. However, the seismic profile obtained by Glomar Challenger (Figure 3) showing a flat sea bed underlain by a layered sequence did give the impression of at least some 100 meters of sediment, and on this basis Site 226 was chosen. A subsequent profile across the Site 226 beacon,
TABLE 5

Interstitial Water Data ${ }^{a}$

\begin{tabular}{lccccc}
\hline \multicolumn{1}{c}{ Sample } & $\begin{array}{c}\text { Subbottom } \\
\text { Depth } \\
(\mathrm{m})\end{array}$ & $\begin{array}{c}\mathrm{H}_{2} \mathrm{O} \\
\text { Recovered } \\
(\mathrm{ml})\end{array}$ & $p \mathrm{H}$ & $\begin{array}{c}\text { Temp. } \\
\left({ }^{\circ} \mathrm{C}\right)\end{array}$ & $\begin{array}{c}\text { Salinity } \\
(\text { Corr. }) \\
(\%)\end{array}$ \\
\hline Surface Seawater & & & 8.72 & 26.0 & 39.5 \\
1-1, all & 1 & 90 & 6.13 & 25.8 & 256 \\
$1-2,0$ to $10 \mathrm{~cm}$ & 2 & 21 & 6.07 & 25.7 & 256 \\
$1-3,5$ to $11 \mathrm{~cm}$ & 4 & 30 & 6.04 & 26.1 & $265^{\mathrm{b}}$ \\
$1-4$ & 5 & 150 & 6.42 & 26.2 & $264^{\mathrm{b}}$ \\
\hline
\end{tabular}

${ }^{\mathrm{a}}$ F. Manheim and D. Marsee were the analysts. Water diluted by weight with distilled water prior to determination of salinity by refractive index.

bValues have uncertain validity (possible evaporation or contact with dried salt on surfaces. Note also that refractometry is no longer strictly related to total salt content for these extremely salty brines.)

obtained on the way to Site 227 , appeared to confirm this impression (Figure 4). Nevertheless, due to near-surface basalt, the bit was prevented from deeper penetration and the question of the presence of underlying sediment could not be resolved.

\section{DISCUSSION AND CONCLUSIONS}

Site 226 was drilled in an area where Glomar Challenger-23 and earlier seismic profiles suggested that a sedimentary sequence adequate for drilling was present. However, a hard basaltic layer lying near the sea bed restricted penetration on six attempts to only 14 meters. Only two stratigraphic units were observed:

Unit I: A mixed montmorillonite, anhydrite, and goethite-hematite facies (total thickness of $5 \mathrm{~m}$ ).

Unit II: Relatively fresh fragments of basalt and basaltic glass (total thickness $9 \mathrm{~m}$, though not definite that basalt was $9 \mathrm{~m}$ thick).

Unit I was found in a badly disturbed core, the mineral facies observed are similar to those described by Bischoff (1969) from a more detailed study. Because of the disturbed state of the core, little can be added to Bischoff's observations.

The basalt fragments occasionally show chilled glassy margins which represent the outer surface of pillows or the upper parts of extruded lava. The fragments are remarkably unaltered, suggesting no chemical reaction between the basalt and the hot brine solution during the cooling of the basalt. Mineralogically, the basalts are similar to previously described oceanic ridge basalts. It is conceivable that heavy metal-rich sediments occur below the basalts.

Only rare and poorly preserved Late Quaternary fossils were found.

Geochemically, the disturbed sediments obtained at Site 226 differ somewhat from the previously described sediments. In particular, sediments from Site 226 have less manganese (less than $0.1 \%$ ) but more barium (more than $0.5 \%$ ) and lead (up to $0.5 \%$ ).

Deuterium content is similar to that of the overlying seawater (Friedman and Hardcastle, this volume), supporting previous ideas that the brines are Red Sea water that has been heated and enriched with various elements, which in part have come from the evaporite sequence. 


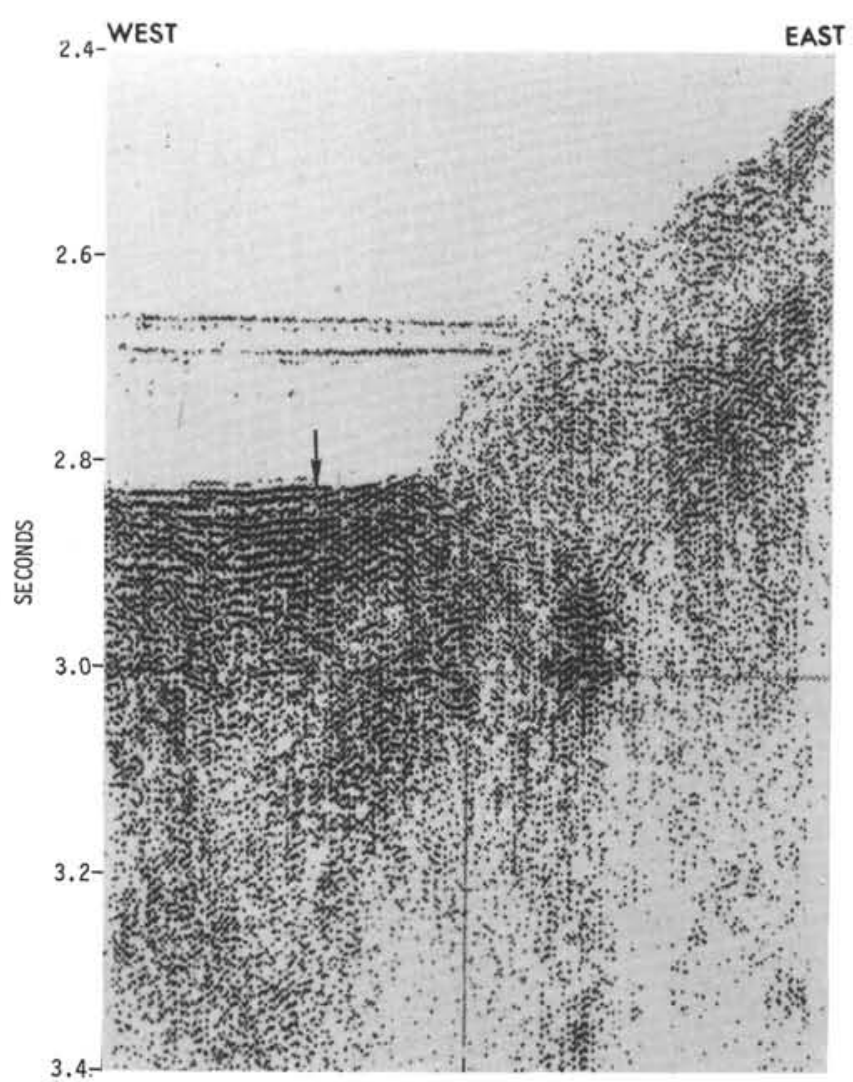

Figure 3. Seismic profile obtained on arriving at Site 226. The arrow indicates where the acoustic beacon was launched.

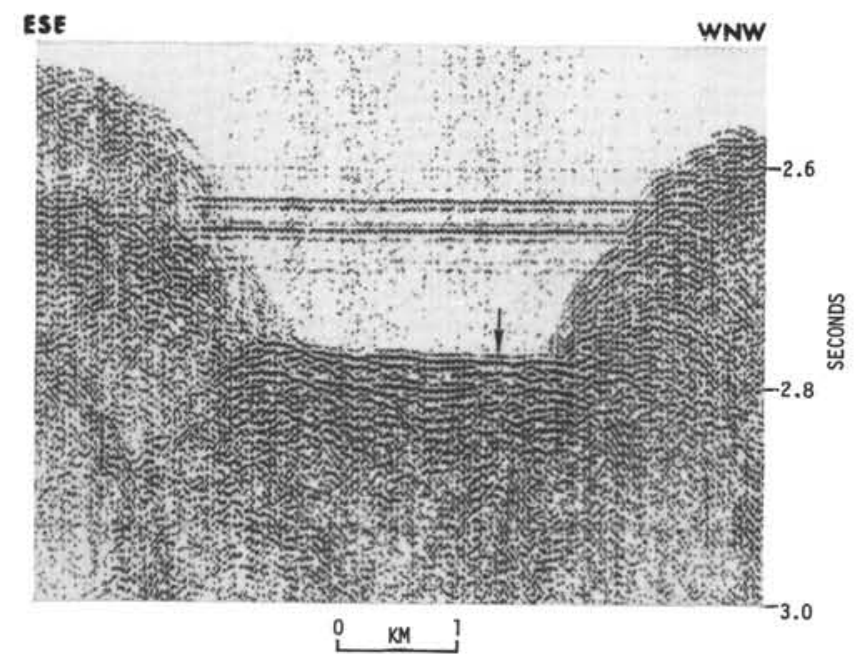

Figure 4. Seismic profile across the Site 226 acoustic beacon which is shown by the arrow.
Seismic profiles from the hot brine area (Ross et al., 1969; Ross et al., 1973; Geophysical Appendix, this volume) show a coincidence in the depth of reflector $\mathrm{S}$ (the top of the evaporite sequence) and the level of the brine. If this coincidence is significant, it suggests that wherever the evaporites crop out in a closed depression, a brine pool is possible. The enrichments of heavy metals in the shales and muds within the evaporites and above them (see reports for Sites 225, 227, and 228) suggest a possible source for some of the metals while the evaporites themselves could provide some of the salts found in the hot brines. Recently German scientists (Bäcker and Schoell, 1972) have discovered 13 new brine pools, but unforturnately they did not have seismic profiling equipment to test the above idea.

\section{REFERENCES}

Amann, H., 1972. Marine/raw material exploration with the Valdivia: Meerestechnik, v. 3, p. 102-106.

Bäcker, H. and Schoell, M., 1972. New deeps with brines and metalliferous sediments in the Red Sea: Nature Phys. Sci., v. 240, p. 153-158.

Bischoff, J. L, 1969. Red Sea geothermal brine deposits, their mineralogy, chemistry and genesis. In Degens, E. T. and Ross, D. A. (Eds.), Hot brines and recent heavy metal deposites in the Red Sea: New York (Springer-Verlag), p. 368-401.

Brewer, P. G., Wilson, T. R. S., Murray, J. W., Munns, R. G., and Densmore, C. D., 1971. Hydrographic observations on the Red Sea brines indicate a marked increase in temperature: Nature, v. 231 , p. 37-38.

Degens, E. T. and Ross, D. A. (Eds.), 1969. Hot brines and recent heavy metal deposits in the Red Sea: New York (Springer-Verlag), p. 535-541.

Laughton, A. S., 1970. A new bathymetric chart of the Red Sea: Roy. Soc. London Phil. Trans., Series A, v. 269, p. 21-22.

Miller, A. R., Densmore, C. D., Degens, E. T., Hathaway, J. C., Manheim, F. T., McFarlin, P. F., Pocklington, R., and Jokela, J., 1966. Hot brines and recent iron deposits in deeps of the Red Sea: Geochem. Cosmochim. Acta, v. 30 , p. 341 .

Moore, J. G., 1970. Water content of basalt erupted on the ocean floor: Contr. Mineral. Petrol., v. 28, p. 272-279.

Ross, D. A., 1971. Red Sea hot brine area: revisited: Science, v. 175 , p. $1455-1457$.

Ross, D. A., Hays, E. E., and Allstrom, F. C., 1969. Bathymetry and continuous seismic profiles of the hot brine region of the Red Sea. In Degens, E. T. and Ross, D. A. (Eds.), Hot brines and recent heavy metal deposits in the Red Sea: New York (Springer-Verlag), p. 82-97.

Ross, D. A. and Hunt, J. M., 1967. Third brine pool in the Red Sea: Nature, v. 213 , p. 687.

Ross, D. A., Whitmarsh, R. B., Ali, S. A., Boudreaux, J. E., Coleman, R., Fleisher, R. L., Girdler, R., Manheim, F., Matter, A., Nigrini, C., Stoffers, P., and Supko, P. R., 1973. Red Sea Drillings: Science, v. 179 , p. 377-380.

Swallow, J. C. and Crease, J., 1965. Hot salty water at the bottom of the Red Sea: Nature, v. 205, p. 165. 